Ankara Üniversitesi Türk Inkllâp Tarihi Enstitüsü Atatürk Yolu Dergisi

S 37-38, Mayıs-Kasim 2006, s. 77-101

\title{
İngiliz Muhibler Cemiyeti Hakkında Bazı Notlar ve Belgeler
}

\author{
Doç. Dr. Mehmet DEMIRYÜREK*
}

\section{ÖZET}

Bu çalışmanın amacı İngiliz Muhipler Cemiyeti ile ilgili bazı belgeleri ortaya çıkarmak ve değerlendirmektir. Ingiliz Muhipleri Cemiyeti Mütareke Devri'nde Sait Molla tarafından kuruldu. Cemiyetin lideri Sait Molla bütün belediye başkanlıklarına bir telgraf göndererek cemiyetin şubelerinin açılmasını ve İngiliz mandasının istenildiğini hükûmete, müttefik temsilciliklerine ve gazetelere telgrafla bildirilmesini istedi. Çünkü, ona gore tek kurtuluş yolu Ingiliz mandasının kabulü idi.

Anahtar Kelimeler : Ingiliz Muhibler Cemiyeti, Sait Molla, İstanbul Hükûmeti

\section{ABSTRACT}

The aim of this study is to reveal and evaluate some documents about the English Frendship Association was established by Sait Molla in the period of Mudros Armistice. It was founded in 1919. It's leader, Said Molla, sent e telegraph all mayoralities and wanted that the Turkish people should establish the branches of that association everywhere, wanted the British Mandate, and sent telegraphs to the Turkish Government in Istanbul, the representatives of Allied Powers and the newspapers. Because, according to Said Molla, the only salvation way was the British mandate. But Said Molla was not supported by the Turkish Government and the Turkish People.

Key Words: English Frendship Association, Sait Molla, İstanbul Government

\section{GİRIŞ}

İngiliz Muhipler Cemiyeti, faaliyetleri ve temsil ettiği zihniyet açısından Mütareke Dönemi'nin (1918-1922) önemli kuruluşlarından biridir. Cemiyetle ilgili yapılmış bazı çalışmalar vardır. Bu cümleden olarak Tarık

\footnotetext{
• Lefke Avrupa Üniversitesi Fen-Edebiyat Fakültesi Tarih Bölümü.
} 
Zafer Tunaya"'nın, Fethi Tevetoğlu²'nun, Cengiz Dönmez'in ve Musa Çadırcı''nın çalışmaları zikredilebilir. Konuyu en son inceleyenlerden birisi olan Cengiz Dönmez'in çalışmasında (Ankara 1999) Türk İnkılap Tarihi Arşivi'ndeki bol sayıda bulunan belgeler kullanılmadığı gibi, bu eserde ek olarak yayımlanan hiçbir belge de doğrudan doğruya İngiliz Muhipler Cemiyeti ile ilgili değildir. Fethi Tevetoğlu'nun çalışmasının daha eski, ama daha kapsamlı ve değerli olduğu dikkati çekmektedir. Musa Çadırcı'nın makalesi ise doğrudan doğruya belge yayını özelliği taşımakta olup çok kıymetlidir. Ama kendisinin de belirttiği üzere sınırlıdır. Bu nedenlerle konunun ileride bir başka araştırmacı tarafından yeniden ele alınması gerekecektir.

Bizim amacımız ise konuyu ileride ele alacak araştırmacıya yardımcı olacak bazı belgeleri değerlendirerek yayımlamaktır. Bu maksat doğrultusunda Başbakanlık Osmanlı Arşivi'ndeki bazı belgeler ile 1921 yılına ait ve Kastamonu'da bulunmuş ${ }^{5}$ bir not defterindeki bilgileri değerlendirmeye çalışacağız.

\section{İngiliz Muhipleri Cemiyeti'nin Kuruluşu}

İngiliz Muhipleri Cemiyeti'nin 20 Mayıs 1919 tarihinde kurulduğu bilinmektedir. ${ }^{6}$ Yine bilinen bir başka konu da Cemiyet Başkanı Sait Molla imzasıyla, 23 Mayıs 1919 tarihinde bütün belediye başkanlıklarına gönderilen bir telgrafnamenin olduğudur. Bu telgrafnamenin içeriği de kısmen bilinmektedir. Cengiz Dönmez'e göre, "Cemiyetin kuruluşunu gerçekleştiren Said Molla da, Cemiyetin kuruluşuyla ilgili olarak, 23 Mayıs'ta bütün belediye başkanlarına birer telgraf göndererek İstanbul'da Ingiliz Muhibler Cemiyeti'nin kurulduğunu haber vermiştir."7 Fethi Tevetoğlu'na göre ise, "Said Molla (...) bütün belediye başkanlarına birer telgraf göndererek az önce kurulmuş olan cemiyeti yeni mahalli şubeler açmak suretiyle desteklemelerini istedi." ${ }^{8}$ Konuya Nutuk'da değinen Mustafa Kemal Paşa da "O günlerde İngiliz Muhibler Cemiyetiyle birlik

' Tarık Zafer Tunaya, Türkiye'de Siyasal Partiler, Cilt:2, Mütareke Dönemi, İletişim Yayınları, İstanbul 2003, s.463-481. 143.

${ }^{2}$ Fethi Tevetoğlu, Millî Mücadele Yıllarındaki Kurulușlar, TTK, Ankara 1998, s.52-

${ }^{3}$ Cengiz Dönmez, Millî Mücadeleye Karşı Bir Cemiyet:İngiliz Muhibleri Cemiyeti, Atatürk Araștırma Merkezi Yayını, Ankara 1999

${ }^{4}$ Musa Çadıreı, İngiliz Muhibleri Cemiyetine İliş̧in Belgeler, Atatürkçü Bilinç Dergisi, (Akdeniz Üniversitesi Atatürk ilkeleri ve İnkılap Tarihi Araştırma ve Uygulama Merkezi Dergisi), C.1,Sayı:1, Akdeniz Üniversitesi Basımevi, Antalya 1994, s.74-102.

${ }^{5}$ Defter Kastamonulu öğrencim Feyza Büyükdağ tarafından bulunmuş olup kendisinin arşivindedir.

${ }^{6}$ Tarkk Zafer Tunaya, Türkiye'de Siyasal Partiler, Cilt:2, Mütareke Dönemi, İletișim Yayınları, İstanbul 2003, s.463. Ayrıca bkz. yukarıda zikredilen eserler.

${ }^{7}$ Cengiz Dönmez, a.g.e, s.62.

${ }^{8}$ Fethi Tevetoğlu, (Jaschke'den naklen) a.g.e, s.57. "Aynı gün (23 Mayts 1919 Cuma) Said Molla; bir telgrafla bütün belediye başkanlarına 'Istanbul'da Ingiliz Muhibleri Cemiyeti'nin kurulduğunu bildirmiştir." A.g.e, s.62. "Said Molla'nın imzasıyla bütün vilayetlere ve müstakil ilçelere telgraflar çekilmiş, halk bu cemiyete girmeğe davet edilmiştir." A.g.e, s.67. 
olarak bütün ulusça Ingiltere'den yardım istenmesinin bu dernek adına, Said Molla imzasıyla bütün belediye başkanlıklarına bir telle bildirildiğini (...)" belirtmektedir. ${ }^{9}$

\section{Sait Molla'nın Telgrafının İçeriği}

Yukarıda verilen bilgilerden anlaşılacağı üzere konuyla ilgili eserlerde, söz konusu telgrafa ve içeriğine kısaca değinilmekle yetinilmiş, bizim görebildiğimiz kadarıyla, bu telgrafnamenin aslını, kopyasını veya ayrıntılı içeriğini yayımlayan olmadığı gibi, bu telgrafa İstanbul hükûmetinin ve vilayetlerin tepkisini ele alan bir çalışma da yapılmamıştır. İşte biz öncelikle bu konulara açıklık getirmeye çalışacağız.

Söz konusu telgrafnamenin içeriği ile ilgili en ayrıntılı bilgiyi şu ana kadar sadece iki kaynak zikretmiştir. Bunlardan birincisine göre, Sait Molla'nın telgrafında “Dersaadete'te Ingiliz Muhibleri Cemiyeti teşekkül ettiğ $i$ ve her tarafta bu cemiyete iștirak ile Ingiltere müzaheretinin talep edilmesi lüzumu"10 bildirilmekte idi. İkinci kaynağa göre ise "23 Mayıs'ta Istanbul'da Sait Molla imzasile belediye reislerine gelen telgrafta:İstanbul'da Ingiliz Muhipleri Cemiyeti teessüs ettiğini ve vilâyatta dahi bu yegâne selâmet ve necabet yoluna salik olduklarını ve Ingiliz muhabbet ve taraftarlı̆̆ı hususundaki hissiyât-l fevkalade-i umûmiyelerini ve Ingiliz müzaheretini talep ettiklerini bila-istisna tekmil mümessillere ve hükûmete ve gazetelere derhal telgrafla iş'ar edilmesi talep olunuyordu.",l

Başbakanlık Osmanlı Arşivi'nde bulunan belgelere göre ise, Sait Molla'nın telgrafı üzerine bazı vilayetler hükûmete başvurarak duruma açıklık getirilmesini istemişlerdir. Bu telgrafnamelerde Sait Molla'nın söz konusu telgrafı da özetlendiği için telgrafnamenin ayrıntılarını öğrenmemiz mümkün olmaktadır.

${ }^{9}$ Mustafa Kemal Atatürk, Nutuk, Türk Dil Kurumu Yayınları:220/1, Atatürk Dizisi:1, Ankara, Gnkur. Basımevi, 1981, s.20. Atatürkle ilgili başka eserlerde de şu bilgiler vardır: "Said Molla imzasiyla belediye riyasetlerine keşide edilmiß olan malum telgrafnamenin (...)" Mustafa Kemal Atatürk, Nutuk, Cild:3, Vesikalar, MEB yayını, İstanbul 2000, s.914-915, Vesika No:25; "Istanbul'dan Sait Molla imzall bir telgrafin her taraf belediye başkanlıklarına çekildiğini öğrendim.(...)"Atatürk’ün Bütün Eserleri, Kaynak Yayınları, Cilt:3, İstanbul 1999, s.328; "Bes gün evvel Sait Molla imzastyla bütün belediye başkanlarına tamimen gelen bir telgrafta, her tarafta Ingiliz Muhibler Cemiyeti kurulmastyla Ingiliz yardımını isteme cağrısında bulunuluyordu. (...)"Atatürk'ün Bütün Eserleri, Kaynak Yayınları, Cilt:3, Istanbul 1999, s.333; "Ingiliz Muhipler Cemiyeti Baskant Sait Molla, belediye başkanlarına ̧̧ektiği telde, derne ğin kurulduğunu bildirdi. Telgrafta 'Ingiliz mandast istediğinizi bütün itilaf temsilcilerine, hükûmete ve gazetelere bildirin' dedi."Zeki Sarıhan, Kurtuluş Savaşı Günlüğü, I. Cilt, TTK Yayını, Ankara 1993, s.270; “23 Mayıs 1919'da Said Molla imzastyla belediye başkanlarına telgraflar çekilmiş, Istanbul'da Ingiliz Muhibler Cemiyeti'nin kurulduğu ve İstanbul'un tek kurtulus yolu etrafında toplandığı, Ingiliz taraftarlığl ve onların yardımlarının istenmesi ve hükumete, gazetelere bu konuda telgraflar çekilmesi istenmişsti."Berna Türkdoğan, Millî Mücadele Tarihi:Makaleler, Atatürk Araştırma Merkezi, Ankara 2002, s.108.

${ }_{10}$ Türk Palamento Tarihi, Millî̀ Mücadele ve TBMM I. Dönemi 1919-1923, Türkiye Büyük Millet Meclisi Vakfı Yayıları No:4, Ankara 1994, s.44. (Mustafa Kemal Paşa'nın 24 Nisan 1920 tarihli konuşması)

"Kâzım Karabekir, İstiklâl Harbimiz, Türkiye Yayınevi, İstanbul 1960, s.33-34. 
Sait Molla'nın telgrafı üzerine Kütahya'dan, Silifke'den, Sivas'tan, Bursa'dan ve İzmit'ten Dahiliye Nezareti'ne telgraflar gelmiş ve konuyla ilgili olarak hükûmetten açıklama istenilmiştir. ${ }^{12}$

Bu telgraflardan özellikle Bursa ve Kütahya'dan çekilen telgraflar bize Sait Molla'nın telgrafının içeriği hakkında ayrıntılı bilgiler vermektedir. Bursa'dan 24 Mayıs 1919 (Sait Molla'nın telgrafının ertesi günü) tarihinde ve "Vali Vekili Şefik" imzasıyla Dahiliye Nezareti'ne çekilen telgrafnameye göre "Bu kere Dersaadet'te teşekkül eden İngiliz Muhipler Cemiyeti müessislerinden Said Molla Bey tarafindan Belediye Riyaseti'ne çekilen telgrafta vatanımızın imkân-ı istihlâsını te'min için vilayet ahâlisinin hemen cemiyet-i mezkûreye iştirak eylediklerini ve İngiliz muhabbet ve taraftarlığ hususundaki hissiyât-l fevkalade-i umumiyeleriyle İniliz müzahereti talep ettiklerini bila-istisna tekmil mümesillere ve hükûmet ve gazetelere derhal telgrafla iş'ar eylemeleri muktezi idü̆̆̈̈ (...)"'s bildirilmiştir.

Kütahya'dan 25 Mayıs 1919 (Sait Molla'nın telgrafından 2 gün sonra) tarihinde "Mutasarrıf Fevzi" imzasıyla Dahiliye Nezareti'ne gönderilen telgrafnameye göre ise "Said Molla imzasiyla belediye riyasetine çekilen telgrafnamede vatanın imkân-ı istihlâsını İngiliz müzaheretinde gören heyet İngiliz Muhibleri Cemiyeti'ni teşkil ettiklerinden vilâyattaki ahâlinin de bu cemiyete iştirak eylediklerini ve İngiliz muhabbet ve taraftarlığı hakkındaki hissiyât-ı umumiyelerini ve İngiliz müzaheretini talep ettiklerini bilâ-istisna tekmil mümessillere ve hukûmete ve gazetelere telgrafla iş'ar eylemeleri lüzumu bildirilmektedir." 14

Silifke, Sivas ve İzmit'ten gelen telgraflar ise yukarıdakiler kadar ayrıntılı değildir. Örneğin Silifke'den gelen telgrafa göre, "Dersaadette teşekkül etmiş olan İngiliz Muhibleri Cemiyeti tarafından Belediye Riyaseti'ne çekilen telgrafta vatanımızın ümid-i istihlâsı İngiliz müzaheretinde görüleceği anlaşıldı̆̆ından vilayetçe Ingiltere taraftarlı̆̆ hakkında hükûmete ve düvel-i itilâfiye mümessillerine müracaat edilmesi" "IS istenilmiştir.

${ }_{12}$ Başbakanlık Osmanlı Arşivi, Tasnifin Kodu: DH.KMS, Tarih: 1331.S.26, Dosya No: $52-1$, Gömlek No:98

${ }^{3}$ Başbakanlık Osmanlı Arşivi, Tasnifin Kodu: DH.KMS, Tarih: 1331.S.26, Dosya No: 52-1, Gömlek No:98.

${ }^{14}$ Başbakanlık Osmanlı Arşivi, Tasnifin Kodu: DH.KMS, Tarih: 1331.S.26, Dosya No: 52-1, Gömlek No:98.

${ }^{15}$ Başbakanlık Osmanlı Arșivi, Tasnifin Kodu: DH.KMS, Tarih: 1331.S.26, Dosya No: 52-1, Gömlek No:98; Sivas'ta gelen Telgrafname de ise "Said Molla imzastyla Belediye'ye varid olan telgrafnamede Ingiltere Devleti'nin müzaheretine müracaat etmek üzere İngiliz Muhibbler Cemiyeti teşkil ettiğinden taşralarda dahi böyle heyetin teşkil ve Ingiliz mümessiline müracaat eylemesi beyan olunmus (...)" tur, denilirken Izmit'ten gelen telgrafta ise sadece "Ingiliz Muhibleri Cemiyeti namına Said Molla tarafindan Belediye riyasetine gelen telgrafnamede her taraftan İngiliz müzaheretine müracaat olunmast (...)"nın istenildiği belirtilmektedir. 
Yukarıda zikrettiğimiz telgrafları göz önüne aldığımız zaman 23 Mayıs 1919 (Cuma) tarihinde Sait Molla imzasıyla belediye başkanlıklarına gönderilen telgrafın içeriğinin şu maddelerden oluştuğunu söyleyebiliriz:

1.İngiliz Muhipler Cemiyeti kurulmuştur. Cemiyeti kuranlar vatanın kurtuluş imkanını İngiliz "müzaheretinde" görmektedirler.

2.Vatanın kurtuluş imkanını temin için vilayet halkı hemen bu cemiyete katılmalıdır.

3.Halk bu cemiyete katıldığını, İngilizseverlik ve İngiliz taraftarlığı hakkındaki genel hislerini ve İngiliz "müzaheretini" talep ettiğini İstanbul'daki bütün yabancı temsilciliklere, hükûmete ve gazetelere telgrafla bildirmelidir.

\section{Sait Molla'nın Telgrafı ve İstanbul Hükûmeti'nin Tutumu}

Sait Molla'nın bu telgrafı çektiği sırada Sadrazam Damat Ferit Paşa'dır. Dahiliye Nazırı ise Ali Kemal Bey ${ }^{16}$ 'dir. Telgrafa ilk tepki, Sait Molla'nın telgrafı ile aynı tarihi taşımaktadır. 23 Mayıs 1919 tarihli olan ve "İzmit Mutasarrıfi Ahmet" imzasını taşıyan telgrafnamede, İngiliz Muhipler Cemiyeti adına Said Molla tarafından Belediye Başkanlı̆̆ı'na bir telgraf gönderildiği, bu telgrafta her taraftan "Ingiliz müzaheretine müracaat"edilmesinin istenildiği ifade edildikten sonra "Bu babdaki iradeleri müsta'ciliyet ve ehemmiyetle müsterhamdır." ${ }^{17}$ deniliyordu.

24 Mayıs'ta Dahiliye Nezareti Şifre Kalemi'ne ulaşan 23 Mayıs 1919 tarihli bu telgrafa Hükûmetin hemen cevap vermediği anlaşılmaktadır. Çünkü bu telgraf ancak 24 Mayıs 1919 tarihli olan ve Bursa'dan gelen telgrafname ile birlikte 24 Mayıs 1919 tarihinde Dahiliye Nezareti Kalem-i Mahsus Müdüriyeti'nden Sadrazamlığa gönderilmiştir. Sadrazamlığa gönderilen bu yazıda şöyle denilmektedir:

"İstanbul'da müteșekkil İngiliz Muhibleri Cemiyeti namına Said Molla Bey tarafindan belediye riyasetine çekilen telgrafnamede her taraftan İngiliz müzaheretine müracaat olunması lüzumu bildirildiğinden bahis ile istifsar-l muameleyi havi Hüdavendiğâr vilayetiyle İzmit Mutasarrıflığı'ndan alınan telgrafnamelerin suretleri leffen takdim kılınmış ve bu müracaatın bütün vilâyata şamil olduğu cereyan-ı halden anlaşılmış olmağla iktizasının emr ve inba buyurulmasi ma'ruzdur. Ol babda." 18

Sadaret makamının bu yazıya ne cevap verdiği şu an için malumumuz değildir. Bununla birlikte Kütahya Mutasarrıfının konuyla ilgili olarak

${ }^{16}$ Türk Parlamento Tarihi, Meşrutiyete Geçiş Süreci: I. ve II. Meşrutiyet, I. Cilt., Türkiye Büyük Millet Meclisi Vakfı yayınları: No:14, Ankara 1997, s.328-331.

${ }^{17}$ Başbakanlık Osmanlı Arşivi, Tasnifin Kodu: DH.KMS, Tarih: 1331.S.26, Dosya No: 52-1, Gömlek No:98.

${ }^{18}$ Başbakanlık Osmanlı Arşivi, Tasnifin Kodu: DH.KMS, Tarih: 1331.S.26, Dosya No: 52-1, Gömlek No:98. 
Dahiliye Nezareti'ne gönderdiği telgrafta ve Dahiliye Nezareti'nden cevaben yazılan telgrafta ilginç bir ifade bulunmaktadır.

"Kütahya Mutasarrıfı Fevzi" imzalı olan ve Dahiliye Nezareti'ne gönderilen telgrafa göre "Tarihi münasebetler dolayısıyla zaten bütün Osmanlılar İngiliz muhibbi olmakta müttehid ise de şeklen İngilizliğe hasr edilen rabıta-i samimiyetin sair düvel-i itilafiye mümessilleriyle matbuata aks ettirilmesi başka nokta-i nazarla mahzurlu"dur. Bu nedenle Kütahya mutasarrıfı Dahiliye Nazırı'nın "mütalâa-i devletleri"nin bildirilmesini istemektedir. Ancak Mutasarrıf bu "mahzurlu nokta-i nazarların" neler olduğunu açıklamamaktadır.

Kütahya Mutasarrıfı'nın telgrafına Dahiliye Nezareti Kalem-i Mahsus Müdüriyeti'nce "mahrem şifre" ile verilen cevap ise şöyledir:

“Kütahya Mutasarrıflı̆̆ı'na

\section{Mahrem Şifre}

24 Mayıs 335. Ingiliz Muhipleri Cemiyeti hakkındaki mütalâanız musibdir. Hakîmane idare-i maslahat edilmesi mütemennadır." ${ }^{19}$

Kütahya Mutasarrıfı, "Tarihi münasebetler dolaylsılla zaten bütün Osmanlılar İngiliz muhibbi olmakta müttehid ise de şeklen İngilizliğe hasr edilen rabıta-i samimiyetin sair düvel-i itilafiye mümessilleriyle matbuata aks ettirilmesi başka nokta-i nazarla mahzurlu" dur diyerek, Dahiliye Nezareti'nin görüşünü istemiş, ancak "mahzurlu olan nokta-i nazarların" neler olduğunu açıklamamıştı. Bununla birlikte bu cevaptan Mutasarrıflı̆̆ın, İngiliz taraftarlığının açıkça savunulmasını doğru bulmadığı, ama bunu açıkça söylememeyi tercih ettiği sonucunu çıkarabiliriz.

Dahiliye Nezareti ise, Mutasarrıflı̆̆ın yukarıdaki görüşü için, “Íngiliz Muhipleri Cemiyeti hakkındaki mütalâanız musibdir. Hakîmane idare-i maslahat edilmesi mütemennadır."diye cevap verdiğine göre, İngiliz Muhipler Cemiyeti'nin ilk kurulduğu günlerde, başka bir belge elde olmadıkça, İstanbul hükûmetince cemiyetin açıkça desteklenmediği söylenebilir. Hükûmetin bu tavrı takınmasında İzmir'in işgalinin yarattığı tepkiler ve düzenlenen mitinglerin etkili olduğu da düşünülebilir. Ayrıca Atatürk de Nutuk'ta bu konuya değinerek, söz konusu telgrafta açılanan siyasetin "millı̂ bă̆ımsızlı̆̆ımız ile ne dereceye kadar yararlı olabileceğini Bâb-ı âli'den sordum. Uygun görüldü̆̆̈üe ve onaylandığına dair bir cevap almadım" ${ }^{20}$ demektedir.

${ }^{19}$ Başbakanlık Osmanlı Arşivi, Tasnifin Kodu: DH.KMS, Tarih: 1331.S.26, Dosya No: 52-1, Gömlek No:98

${ }_{20}$ Atatürk'ün Bütün Eserleri, Kaynak Yayınları, Cilt:3, İstanbul 1999, s.328. (26 Mayıs 1919 tarihli telgraf); "Bu meselede hükûmetin alâkasının derecesini anlamak için Sadrazam olan Ferit Paşa'dan keyfiyeti istilam ettim, hiçbir cevap alamadım." Türk Palamento Tarihi, Millî Mücadele ve TBMM I. Dönemi 1919-1923, Türkiye Büyük Millet Meclisi Vakfı Yayıları No:4, Ankara 1994, s.44. (Mustafa Kemal Paşa'nın 24 Nisan 1920 tarihli konuşması) 


\section{Sait Molla'nın Telgrafı ve Türkiye Kamuoyu ${ }^{2 l}$}

Sait Molla'nın telgrafının İzmit'te, Bursa'da, Kütahya'da, Sivas'ta ve Silifke'de etki yaratmış olduğu görünmektedir. Telgraf belediye başkanlıklarına çekilmiş olmasına rağmen, görebildiğimiz kadarıyla, İstanbul hükûmeti'nden konuyla ilgili bilgi isteyen belediye başkanlıkları değil, valilik ve mutasarrıflıklar olmuştur. Valilik ve Mutasarrıflıkların söz konusu telgrafları şu kronolojik sırayı izlemektedir:

1. İzmit. 23 Mayıs 1919. "İzmit Mutasarrifi Ahmet" imzalıdır.

2. Bursa. 24 Mayıs 1919. "Vali Vekili Şefik” imzalıdır.

3. Kütahya. 25 Mayıs 1919. "Mutasarrıf Fevzi” imzalıdır.

4. Sivas. 26 Mayıs 1919. "Vali Vekili Hasbi” imzalıdır.

5. Silifke. 27 Mayıs 1919. "Mutasarrıf Vekili Mehmet Ali" imzalıdır.

Dahiliye Nezareti'ne gönderilen bu telgraflarda mutasarrıflık veya valiliklerin görüşleri hakkında bazı ipuçları bulunmaktadır. Buna göre:

1. İzmit Mutasarrıflı̆̆ı herhangi bir görüş bildirmemekte ve " $B u$ babdaki iradeleri müsta'ciliyet ve ehemmiyetle müsterhamdır."diyerek hükûmetten talimat beklemektedir.

2. Bursa valiliğinin görüşü ilginçtir. Valiliğe göre, "Halk esasen hissiyât-l cerihadarını bu sırada lüzumu vechile mümessilîn-i müşarunileyhime arz ve iblăgdan ve makamât-l aliye-i saireye temhidden geri kalmamakta"dır. Bu nedenle “Molla Bey'in bu tebliği şayan-l teemmül ve nazar-ı dikkat" olmamıştır. Öyleyse denilebilir ki, Bursa Valiliği Sait Molla'nın isteklerine olumlu gözle bakmamaktadır.

3. Kütahya Mutasarrıflığı da Sait Molla'nın isteklerini olumlu bulmamaktadır. Mutasarrıfa göre, "Tarihi münasebetler dolayısıyla zaten bütün Osmanlılar İngiliz muhibbi olmakta müttehid ise de şeklen İngilizliğe hasr edilen rabita-i samimiyetin sair düvel-i itilafiye mümessilleriyle matbuata aks ettirilmesi başka nokta-i nazarla mahzurlu"dur. Bu yüzden mutasarrıflık Dahiliye Nezareti'nden "mütalâa-i devletleri istizan olunur." diyerek talimat beklemiştir.

4. Sivas Valiliği, telgrafında, Sait Molla'nın telgrafına kısaca değindikten sonra "Gerçi devlet ve millet ve vatanımızı tahlis maksadıyla her ne lazımsa yapmağa müheyyayız."demekte ve şöyle devam etmekte idi: "Lâkin buna dair hükûmetten vilayete veya İtilaf Fırkası Merkez-i Umûmisi'nden bura şu'besine bir iş'ar olmadı̆̆ cihetle bu gibi

${ }^{21}$ Konuyla ilgili olarak, Kütahya'dan, Silifke'den, Sivas'tan, Bursa'dan ve İzmit'ten İçişleri Bakanlığı'na yazılar yazılmıştır. Sadece 5 telgrafa dayanarak "kamuoyunun görüşüdür" diye fikir ileri sürmenin eksikliğinin farkındayız. Bununla birlikte ileride başka telgraflar da bulunduğunda, bu konuda daha sağlam bir düşüncenin ortaya konulabileceğine inaniyoruz. 
telgrafnamenin millet tarafından keşidesinde mahzur-l siyasi olup olmadı̆̆ının sür'at-i iradesi müsterhamdır."

Görüldüğü gibi Sivas valiliği "devlet, millet ve vatanın kurtuluşu için gereken her şeyi yapmaya hazırız" demekte ama Sait Molla'nın istekleri konusunda ne hükûmetten ne de Hürriyet ve İtilaf Fırkası merkezinden kendilerine veya Hürriyet ve İtilaf Fırkası'nın Sivas şubesine bilgi verilmediğini belirtmekte idi. Bu nedenle valilik, Sait Molla'nın istediği şekilde telgraflar çekmenin "siyasî bir mahzuru" olup olmadığını hükûmetten soruyordu. Sonuç olarak Sivas Valiliği'nin de bu konuda hükumetin veya Hürriyet ve İtilaf Fırkası'nın açık talimatı olmadığı sürece harekete geçmeyi doğru bulmadığı söylenebilir.

5. Silifke Mutasarrıf vekilinin imzasını taşıyan telgrafta ise Sait Molla'nın isteklerinin "hükûmetin siyasetine muvafık olup olmadığında"tereddüde düşüldüğü belirtilerek yapılması gereken konusunda hükûmetten talimat beklenmekte olduğu yazılmıştır.

Şu halde denilebilir ki, bu telgraflardan hiç birisi Sait Molla'nın isteklerinin uygun bulunduğu ve bu konuda harekete geçildiği bilgisini vermemekte ve ancak konuyla ilgili olarak hükûmetten talimat beklendiğini yazmaktadır. Ayrıca hem Bursa Valiliği hem de Kütahya Mutasarrıflığı Sait Molla'nın isteklerinin uygunsuzluğunu dile getirmişlerdir. Kütahya Mutasarrıfının telgrafı için, muhtemelen yetkili birisi tarafından, "Mütalaanız musibdir.Hakimâne idare-i maslahat edilmesi", Silifke ve Sivas'tan gelen telgraflara da "hıfzı emir buyurulmuştur."notları düşülmüştür.

\section{Propaganda Amaçlı Bir Mektup}

$\mathrm{Bu}$ arada Sait Molla'nın sahibi olduğu İstanbul gazetesinin 24 Mayıs 1919 tarihli sayısında aşağıdaki mektup yayınlanmıştır.

“Aldığımız Mektuplardan:

Ingiliz Muhibleri Cemiyet-i Muhteremesine

Muhterem Efendiler,

Mütareke için Mondros limanına memurlarımız gittiği zaman bildiklerime birçok lakırdılarla mütareke şeraitiyle vakit geçirilmeyip İngiliz hükûmet-i fahimesinin adaletine ve himayesine iltica ederiz, deyip ișin içinden çıkmalıdır dedimdi. Evet kuyudât-l tarihiyye nokta-i nazarından İnilizlerin bize etmiş oldukları iyilikleri biz Türklerin hiç unutmaması lâzım gelirdi. Ama ne çare olan oldu. Şimdi aklımızı başımıza alıp çaresine bakalım. Ingilizlerin Türklere ettikleri iyilikler gelince (1) Napolyon Bonapart'tan Misir'l alip tekrar Devlet-i Aliyye'ye iade etmesi (2) Rusya Imparatoru Birinci Nikola'nın 1853 senesinde İngiltere'ye Memalik-i Osmaniyye'nin Rusya ile Ingiltere arasinda taksimi teklifine muhalefette bulunması (3) Kırım muharebesinde Türkiye'nin Rus istilasından halâsiçin 
yapmış olduğu fedakârlığı (4) doksan üç harbinde donanmasıyla İstanbul'a gelip Ruslarin İstanbul'a girmesine mümanaatta bulunmasi gibi vukuatı hiçbir vakit kalbimizden çıkarmamalıyız. Demek oluyor ki İngiltere bizi dört defa düşman istilasından kurtarmıştır. Bu nikat-ı nazardan İngilizler bizim eski dost ve müstahlisimizdirler. Bu ana kadar Ingilizlerden bize hiçbir fenalık ve topraklarımıza hiçbir taarruz vaki olmamıştır. Süveyş'ten ta Babül-mendeb'e ve Bab-ül-mendeb'den Hürmüz Boğazı'na ve oradan Basra'ya kadar Arabistan sibih-ceziresi sevahilinde bulunan adalara bahusus Eminönü'nde Valide Hani'nın yeri kadar șerefli ve kıymetli olan ve Süveyș ile Bab-ül-mendeb arasindaki cadde üzerinde bulunan Farsan adalarina ve bunlar gibi mühim noktalarl teşkil eden diğer adalara tecavüz etseydi kim ne diyebilirdi. Fakat böyle ehemmiyetli noktalara tecavüz etmedi. Hatta mezkûr adaların çoğu üzerinde Devlet-i Aliyye'ye tabi olduklarına dair hiçbir alâmet de bulunmazdı. Doğrusunu söylemek lazım gelirse Ingiltere hükûmeti cezair-i mezkûre gibi ehemmiyetli nikatın yabancı ellere geçmemesi için Allah tarafindan memur edilmiş bir bekçi makamında idi.

Efendim, şunu arz etmek istiyorum ki: Yanlış olarak biz İngilizleri düşman telakki ettik. Pek çok yanıldık. Bari bundan sonra yanılmayalım. Ingiliz dostluğuna dört el ile sarılalım. Necatımız ancak Ingilizlere dost olmamızla husûle gelebilecek. Görmeyen ve gezmeyen ve tarih okumayan milletdaşlarımızı ikaz edelim. Daha söyleyecek şeyler çok ise de başımızı ă̆rıtmamak için bu kadar sözü kâfi gördüm. Cemiyet-i muhteremenize aşă̆ıda isimleri yazılanlarl dahil etmenizi rica ederim muhterem efendilerim.

Kızıltoprak'da Kayışdă̆ı yolu üzerindeki hanesinde mukim Bahriye Kolağalı̆̆ı'ndan mütekaid Bahaeddin. Mümaileyhin zevcesi Zeynep ve kerimeleri Şehr-i ziya ve Hadiye ve Sıdıka, Göztepe'de Kömür ticaretiyle meşgul Mehmet." 22

$\mathrm{Bu}$ mektubun, cemiyetin propagandasını yapma amacını taşıdığını, halkın cemiyeti olumlu karşıladığı ve cemiyete üye olmak için adeta yarıştığı izlenimini vermeyi hedeflediği söylenebilir. Kaldı ki, mektubun kimin tarafından yazıldı ̆̆ı da tam olarak belli değildir.

\section{Cemiyetin İstanbul Dışındaki Şubeleri}

İngiliz Muhipleri Cemiyeti'nin İstanbul dişında ${ }^{23}$ Edirne, Giresun, Çorlu, Ankara, Konya ve Eskişehir'de şubelerinin olduğu belirtilmektedir. ${ }^{24}$ Ancak, Başbakanlık Osmanlı Arşivi'nde bulunan ama ne yazık ki hazırlanma tarihi belli olmayan bir belgeye göre ise, İngiliz Muhipleri

${ }^{22}$ İstanbul, 24 Mayıs 1335/1919, s.2. Bu mektup enteresandır. Çünkü cemiyet 23 Mayıs'ta kurulmuş, hemen mektuplar gelmeye başlamış(?) ve bunlardan birisi (?) 24 Mayıs 1919 tarihinde yayımlanmıştır. 84.

${ }^{23}$ Cemiyetin İstanbul şubelerinin isim ve adresleri için bkz. Musa Çadırcı, a.g.e. ,s.82-

${ }^{24}$ Bkz. Cengiz Dönmez, Millî Mücadeleye Karşı Bir Cemiyet:İngiliz Muhibleri Cemiyeti, Atatürk Araştırma Merkezi Yayını, Ankara 1999, s.99-103; 
Cemiyeti'nin sadece Hüdavendigâr vilayeti merkezinde ve Ankara vilayeti Nallıhan kazasında birer şubesi bulunmakta idi. ${ }^{25}$

\section{İngiliz Muhipler Cemiyeti'nin Üyeleri}

İngiliz Muhipler Cemiyeti ile ilgili çalışmalarda cemiyetin üyelerinin kimler olduğu konusunda çeşitli bilgiler vardır. ${ }^{26}$ Bizim bu çalışmamızda söz edeceğimiz isimler ise bir öğrencimiz tarafında Kastamonu'da bulunmuş bir defterdeki kayıtlara dayanmaktadır. Defterdeki birçok kayıttan kaydı tutan kişinin resmi bir görevli, belki de bir polis, olduğu düşünülebilir.

Defter kaydına göre, bu liste 27 Kânun-1 sâni 37 (27 Ocak 1921) tarih ve 238 numaralı yazıdan sonra 937/99 sıra numarasıyla kaydedilmiştir. Bu bölüm "Ingilizlerin hesabına hidmete dahil olup Anadolu'ya gelecekleri müstahber kılınan eşhasdır." başlığını taşımaktadır. Bu başlık altında verilen bilgiye göre "Ingiliz Muhipler Cemiyetine Mensup Kesan" şunlardır:

Eyüp'de Akif Bey

Hariciye Evrak Müdürü

Yusuf Kenan Efendi

\section{Evkaf Müfettişlerinden}

Naşid Bey

Evkaf Levazım Müdürü

Tahsin Bey

Mühendis

İslâmbey'de Ahmet Bey

Dava Vekili

İslâmbey'de Sıdkı Bey

Beyoğlu Posta Memurlarından

Rami karyesinden Mehmet Pehlivan

Alemdarcı Maruf Kadri Pehlivan

Eyüp'de Hafiz Halim Efendi

Eyüp'de Bahçeli Cemal Efendi

\section{Rami Karyesinden Hüsnü Efendi}

Fener merkezinde Kiremit Karakolunda komiser muavini Ramiz İsmail Efendi. Müteferrikada müstahdem komiser muavini Balat civarında sakin Arnavut Şaban Efendi. Komiser muavinlerinden İslâmbey'de Fehmi Bey. Bahriye yüzbaşılarından Fener'de Sami Bey. İkinci komiser Rami'de Hacı Yusuf Damadl Ahmet Efendi. Drakman'da Şevket Efendi. Sabık Hartum gemiler tahsil şubesi muavini Sultan Selim cami'-i şerif Hafiz Cemal Efendi. Arnavutköy merkez memuru Hacı Kemal Efendi. Sultan Selim'de Muhtar

${ }^{25}$ Başbakanlık Osmanlı Arşivi, Tasnifin Kodu: DH.EUM.AYŞ, Dosya No: 64, Vesika No: 40. Bu.belgede birçok parti, dernek ve cemiyetin ülke genelindeki şubelerinin listesi bulunmaktadır. Bununla birlikte ülke genelini kapsayan bu belgede sayın Cengiz Dönmez'in belirttiği yerlerde bu cemiyetin şubelerinin olduğu görülmemektedir. Bu şubeler, eğer varsa, belki bu belgenin hazırlanmasından sonra açılmış olmalıdır. Belge için bkz. Ekler.

${ }^{26}$ Bkz. Fethi Tevetoğlu, a.g.e; Cengiz Dönmez, a.g.e; Musa Çadırcı, a.g.e. ve Tarık Zafer Tunaya, a.g.e. Musa Çadırcı'nın makalesinin ekinde birçok üyenin resmi de bulunmaktadır. 
INGIILIZ MUHIBLER CEMIYETI HAKKINDA BAZI NOTLAR VE BELGELER 87

Bey. Gümrük Muayene Memurlarından Taksim Merkez Memuru Sıdkı Efendi. Darülfünün Tarih Şubesinden Mes'ud. Sultan Ahmet'te Mukim Evkaf Nezareti Mebani-i Vakfiye müderrisi Abdülkerim Bey. Dar-l Hilafet-i Aliye Müfettişlerinden Kalkandereli Vehbi Efendi."

Söz konusu defterdeki bir diğer başlık “Ingiliz Muhipler Cemiyeti Azayı Sabıkasından Olup Elyevm Ingiliz Casus Teşkilatında İstanbul Şubesinde Müstahdem Olanların Bir Kısmı" dır. Bu bölümde yer alan isimler ise şunlardır:

"Eyüplü Hüsnü Efendi

Seyyahiye komiserlerinden Arapgirli Mustafa Efendi

Sabık Polis komiserlerinden Ürgüplü Mustafa Efendi

Ser Komiser Rıza Efendi

Istanbul'da Cihangir'de mukim Rum milletinden Apostol Efendi

Polis Müdürü Hasan Tahsin Bey

Kısm-ı siyasî müdür-i sabıkı Şeref Bey

İmirli Hafiz İbrahim Efendi

Maruf İzmirli Mahmut Bey

İmir vali-i sabıkı Rahmi Bey ile müşareket olan Arnavut Celeb Mustafa

Seyr i sefain müfettişlerinden Stos Efendi

Tayyareci meşhur Mehmet Ali Efendi

Edremitli Veli Efendi

Umûr-ı siyasiyye şubesi sabık mensuplarından ağır topçu mülazımevveli Fahri Efendi

Ingiliz mümessil-i askerîsi nezdinde erhad zabiti Sedad

Giritli Astm Efendi

Hariciye Nezareti mühimmesi müdüriyeti Resmî Hasan Bey

Lapseki Kaymakam-ı sabıkı Hamdi Bey"

SONUÇ

23 Mayıs 1919 tarihinde kurulan İngiliz Muhipler Cemiyeti, Sait Molla imzasıyla, aynı gün, bütün belediye başkanlıklarına gönderdiği bir telgrafla halktan açık destek istemiştir. Ancak bu telgrafa olumlu bir cevabın alınamadığı görülmektedir. Telgrafın ulaştığı belediye başkanlıklarının bağlı olduğu valilik ve mutasarrıflıklar Sait Molla'nın istekleri yönünde harekete geçmemeyi tercih etmişler ve hükûmetten konuyla ilgili talimat beklemişlerdir. Hükûmet ise ne cemiyet lehinde ne de aleyhinde açık bir tavır ortaya koymamıştır. Denilebilir ki, İngiliz Muhipler Cemiyeti ilk kurulduğu günlerde açık olarak halkın veya hükûmetin desteğine sahip olmamıştır. 


\section{BELGE I}

Şifre Telgrafname

Bâb-ı âli

Dahiliye Nezareti

Tarih-i keşidesi:23 Mayıs 35

Şifre Kalemi

Kaleme vürudu:24 Mayıs 35

Mahreci:İzmid

İngiliz Muhibleri Cemiyeti namına Said Molla tarafından Belediye riyasetine gelen telgrafnamede her taraftan İngiliz müzaheterine müracaat olunması iş'ar olunuyor. Bu babdaki iradelerini müsta'ciliyet ve ehemmiyetle müsterhamdır.

23 Mayıs 35

İzmid Mutasarrıfı

Ahmet 
INGILIIZ MUHIBLER CEMIYETI HAKKINDA BAZI NOTLAR VE BELGELER 89

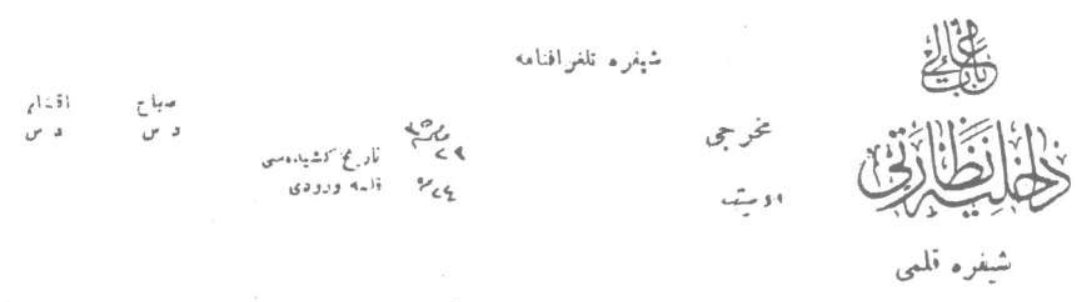

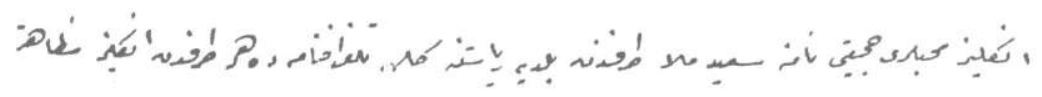

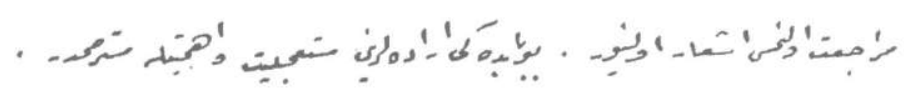

1

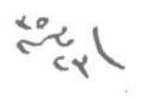

آحم

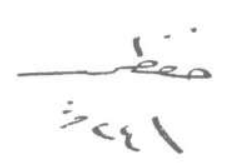




\section{BELGE II}

Şifre Telgrafname

Bâb-ı âli

Dahiliye Nezareti

Şifre Kalemi
Tarih-i keşidesi:24 Mayıs 35

Kaleme vürudu: 24 Mayıs 35

Mahreci:Bursa

Bu kere Dersaadet'te teşekkül eden İngiliz Muhipler Cemiyeti müessislerinden Said Molla Bey tarafından Belediye Riyaseti'ne çekilen telgrafta vatanımızın imkân-ı istihlâsını te'min için vilayet ahalisinin hemen cemiyet-i mezkûreye iştirak eylediklerini ve İngiliz muhabbet ve taraftarlığı hususundaki hissiyât-ı fevkalade-i umumiyeleriyle ingiliz müzahereti talep ettiklerini bila-istisna tekmil mümesillere ve hükûmet ve gazetelere derhal telgrafla iş'ar eylemeleri muktezi idüğü bildiriliyor. Halk esasen hissiyât-ı cerihadarını bu sırada lüzumu vechile mümessilîn-i müşarunileyhime arz ve iblağdan ve makamât-1 aliye-i saireye temhidden geri kalmamakta bulunmasına nazaran Molla Bey'in bu tebliği şayan-ı teemmül ve nazar-ı dikkat olmadı. Ferman.

23/24 Mayıs 35

Vali Vekili

Şefik 
INGILIZ MUHIBLER CEMIYETI HAKKINDA BAZI NOTLAR VE BELGELER 91

$$
\begin{aligned}
& \text { نبغر. • نعرامناما }
\end{aligned}
$$

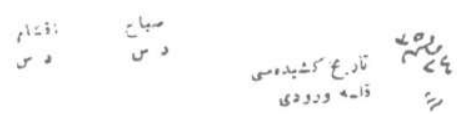

$$
\begin{aligned}
& \text { S. } \\
& \text { (4) }
\end{aligned}
$$

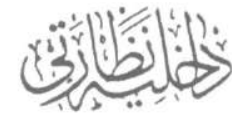

$$
\begin{aligned}
& \text { شبغر. تلمى }
\end{aligned}
$$

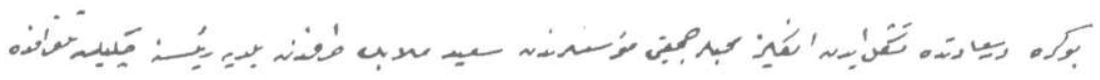

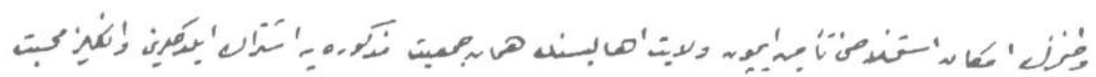

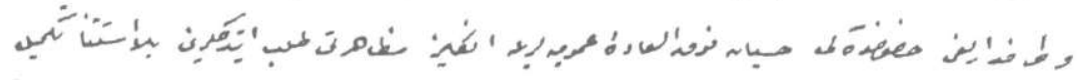

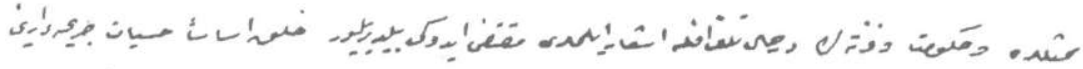

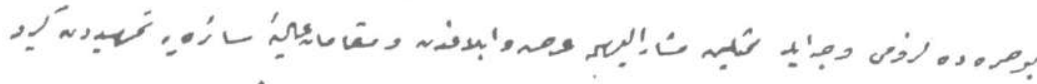

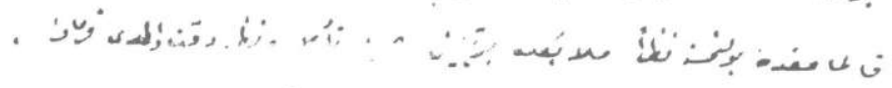

$$
\begin{aligned}
& \text { و'كביב } \\
& \text { شعبه } \\
& \stackrel{2 \pi}{\frac{\alpha u}{L}}
\end{aligned}
$$




\section{BELGE III}

Şifre Telgrafname

Bâb-ı âli

Dahiliye Nezareti

Şifre Kalemi
Tarih-i keşidesi:25 Mayıs 35

Kaleme vürudu: 25 Mayıs 35

Mahreci:Kütahya

Said Molla imzasıyla belediye riyasetine çekilen telgrafnamede vatanın imkân-ı istihlâsını İngiliz müzaheretinde gören heyet İngiliz Muhibleri Cemiyeti'ni teşkil ettiklerinden vilâyattaki ahâlinin de bu cemiyete iştirak eylediklerini ve İngiliz muhabbet ve taraftarlığı hakkındaki hissiyât-ı umumiyelerini ve İngiliz müzaheretini talep ettiklerini bilâ-istisna tekmil mümessillere ve hukûmete ve gazetelere telgrafla iş'ar eylemeleri lüzumu bildirilmektedir. Tarihi münasebetler dolayısıyla zaten bütün Osmanlılar İngiliz muhibbi olmakta müttehid ise de şeklen İngilizliğe hasr edilen rabıta-i samimiyetin sair düvel-i itilafiye mümessilleriyle matbuata aks ettirilmesi başka nokta-i nazarla mahzurlu görüldüğünden mütalâa-i devletleri istizan olunur. 24 Mayıs 35

Mutasarrif

Fevzi

Mütalâanız musibdir. Hakîmâne idare-i maslahat edilmesi. 
INGILIZ MUHIBLER CEMIYETI HAKKINDA BAZI NOTLAR VE BELGELER 93

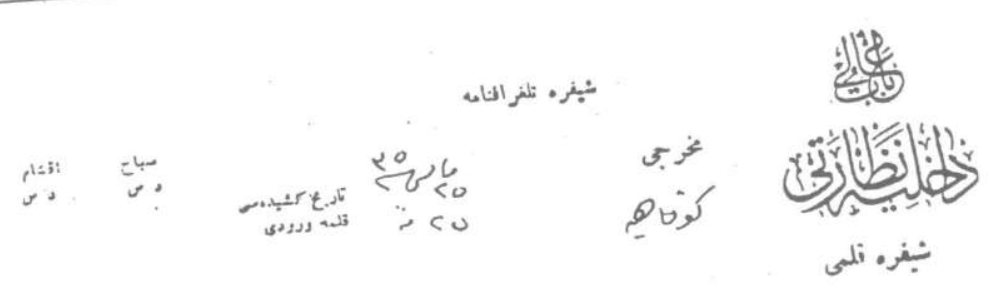

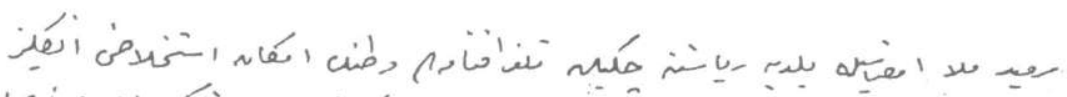

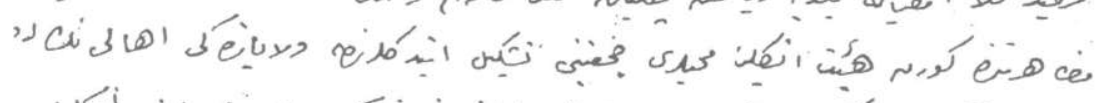

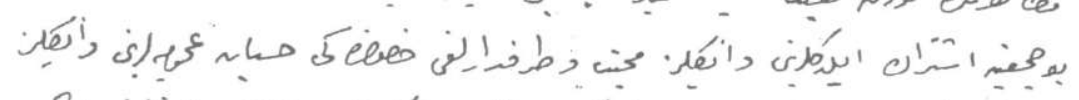

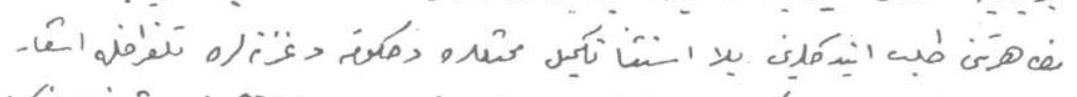

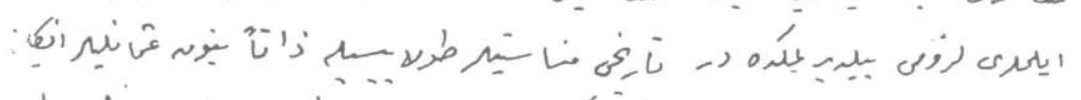

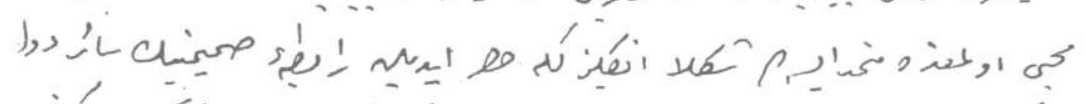
أivo نer

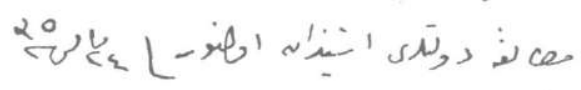
مرنى من

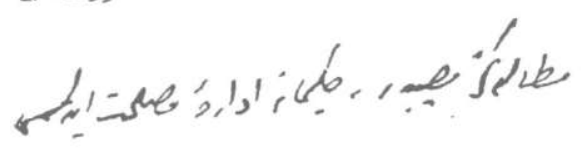




\section{BELGE IV}

Şifre Telgrafname

Bâb-ı âli

Dahiliye Nezareti

Şifre Kalemi
Tarih-i keşidesi:26 Mayıs 35

Kaleme vürudu: 27 Mayıs 35

Mahreci:Sivas

Gayet müsta'celdir.

Said Molla imzasıyla Belediye'ye varid olan telgrafnamede Íngiltere Devleti'nin müzaheretine müracaat etmek üzere Íngiliz Muhibbi Cemiyeti teşkil ettiğinden taşralarda dahi böyle heyetin teşkil ve Íngiliz mümessiline müracaat eylemesi beyan olunmuş ve gerçi devlet ve millet ve vatanımızı tahlis maksadıyla her ne lazımsa yapmağa müheyyayız. Lâkin buna dair hükûmetten vilayete veya İtilaf Frrkası Merkez-i Umûmisi'nden bura şu'besine bir iş'ar olmadığı cihetle bu gibi telgrafnamenin millet tarafından keşidesinde mahzur-ı siyasi olup olmadığının sür'at-i iradesi müsterhamdır.

25 Mayıs 335

\section{Vali vekili}

Hasbi

Hıfzı emir buyurulmuştur.

27 Mayıs 35

(Kalem-i Mahsus) 
INGILIZ MUHIBLER CEMIYETI HAKKINDA BAZI NOTLAR VE BELGELER 95

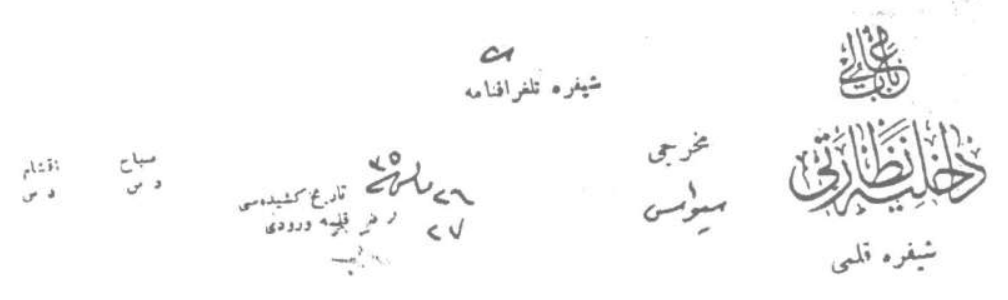

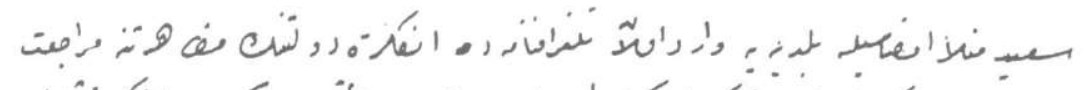

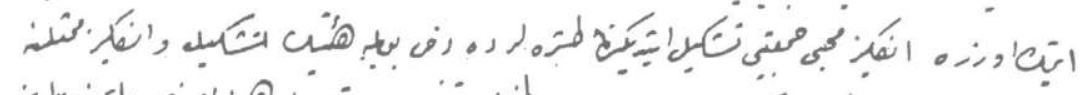

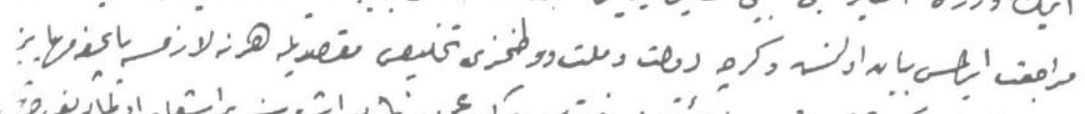

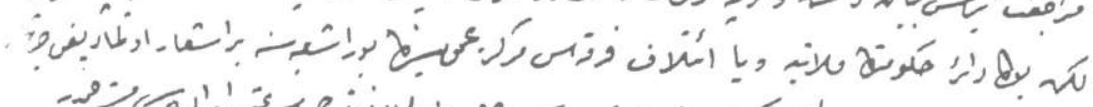

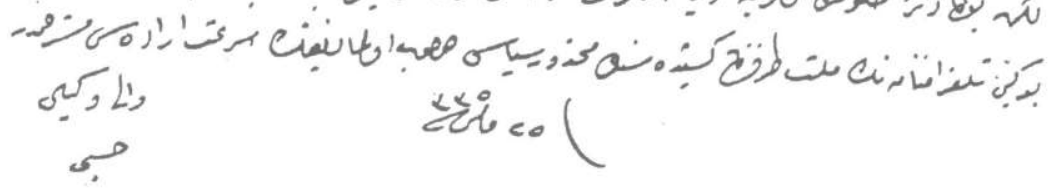




\section{BELGE V}

Şifre Telgrafname

Bâb-ı âli

Dahiliye Nezareti

Tarih-i keşidesi:27 Mayıs 35

Şifre Kalemi

Kaleme vürudu: 27 Mayıs 35

Mahreci:Silifke

Dersaadette teşekkül etmiş olan İngiliz Muhibleri Cemiyeti tarafından Belediye Riyaseyi'ne çekilen telgrafta vatanımızın ümid-i istihlâsı İngiliz müzaheretinde görüleceği anlaşıldığından vilayetçe İngiltere taraftarlığı hakkında hükûmete ve düvel-i itilâfiye mümessillerine müracaat edilmesi iş'ar edilmiş ise de bu hususun hükûmetin siyasetine muvafık olup olmadığında tereddüd edilmekte olduğundan iktizasının emr ve iş'ar buyurulmasına muntazırım. 26 Mayıs 35.

Mutasarrıf Vekili

Mehmet Ali

Hıfzı emir buyurulmuştur.

27 Mayıs 35.

(Kalem-i Mahsus) 


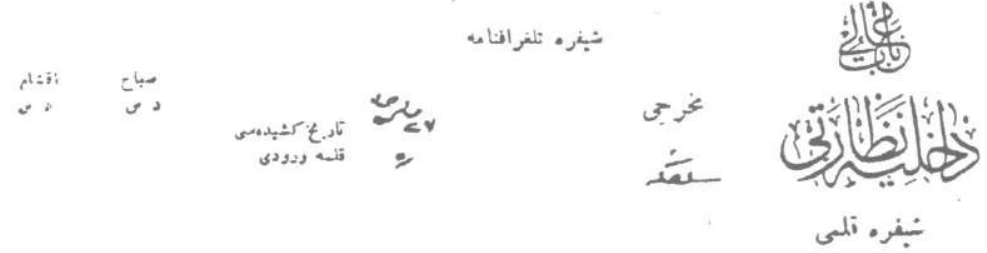

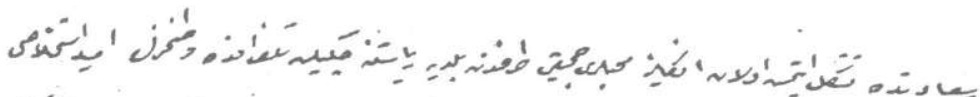

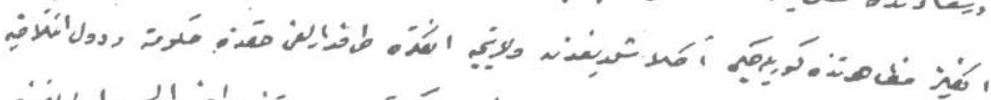

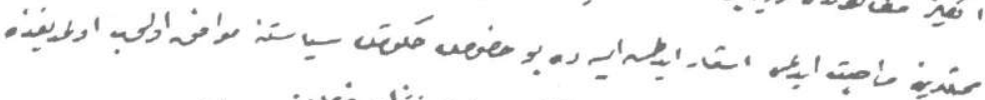

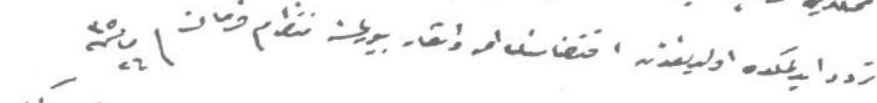
שi: كوي

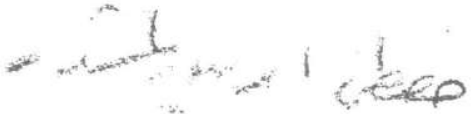
$-c 1$ (कos 


\section{BELGE VI}

Dahiliye Nezareti Kalem-i Mahsus Müdüriyeti

Tarih-i Tebyiz: 24 Mayıs 35

\section{Huzur-ı Âli-i Hazret-i Sadaretpenahiye}

İstanbul'da müteşekkil İngiliz Muhibleri Cemiyeti namına Said Molla Bey tarafından belediye riyasetine çekilen telgrafnamede her taraftan Ingiliz müzaheretine müracaat olunması lüzumu bildirildiğinden bahis ile istifsar-1 muameleyi havi Hüdavendiğâr vilayetiyle İzmid Mutasarrıflığı'ndan alınan telgrafnamelerin suretleri leffen takdim kılınmış ve bu müracaatın bütün vilâyata şamil olduğu cereyan-ı halden anlaşılmış olmağla iktizasının emr ve inba buyurulması ma'ruzdur. OI babda.

(Tebyiz) 


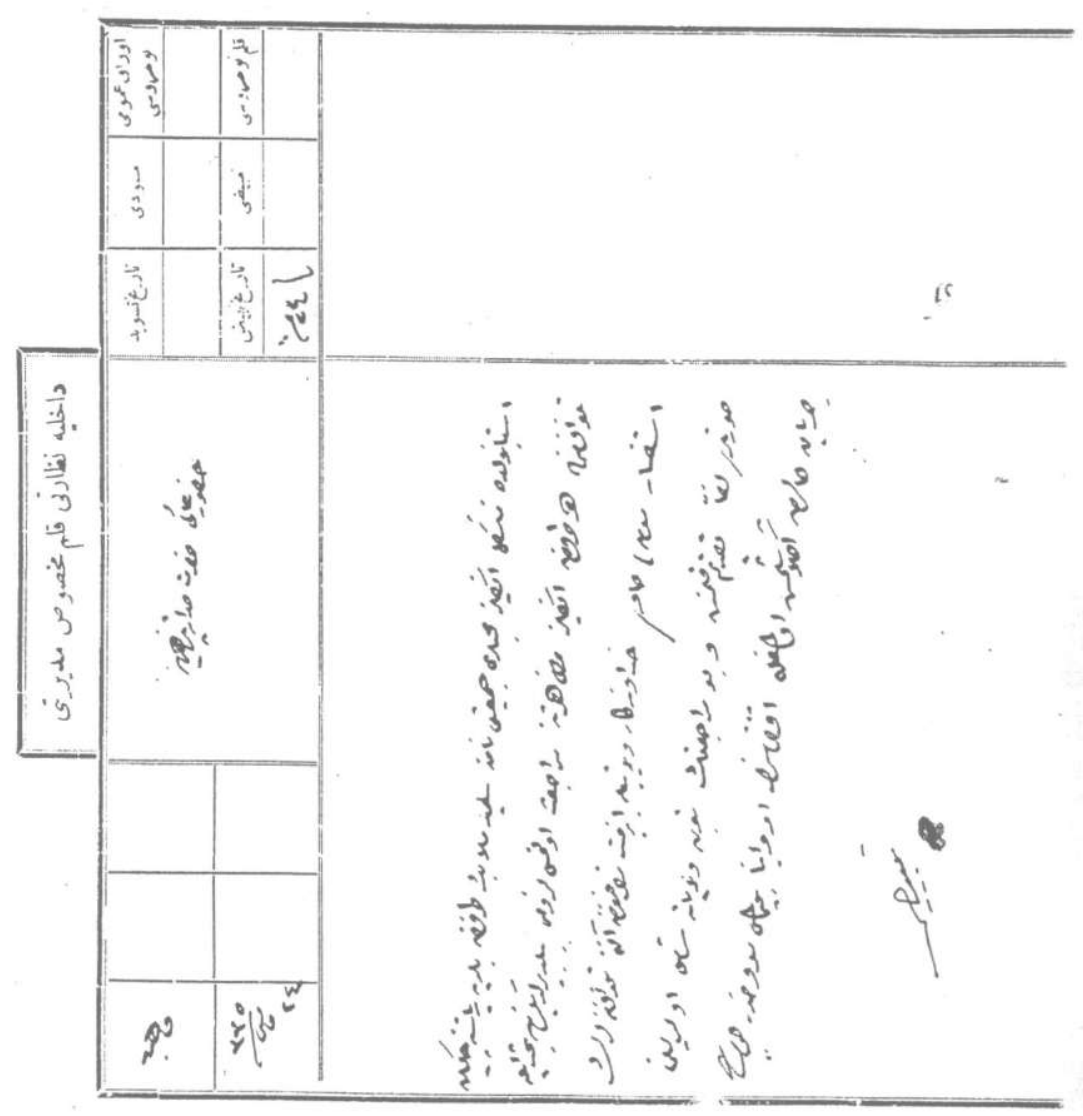




\section{BELGE VII}

Dahiliye Nezareti Kalem-i Mahsus Müdüriyeti

Kütahya Mutasarrıflığı'na

Mahrem Şifre

(Tarih-i tebyiz: 25 Mayıs 335)

24 Mayıs 335 Íngiliz Muhipleri Cemiyeti hakkındaki mütalâanız musibdir. Hakîmane idare-i maslahat edilmesi mütemennadır. 
INGILIZIZ MUHIBBLER CEMIYETI HAKKINDA BAZI NOTLAR VE BELGELER 101

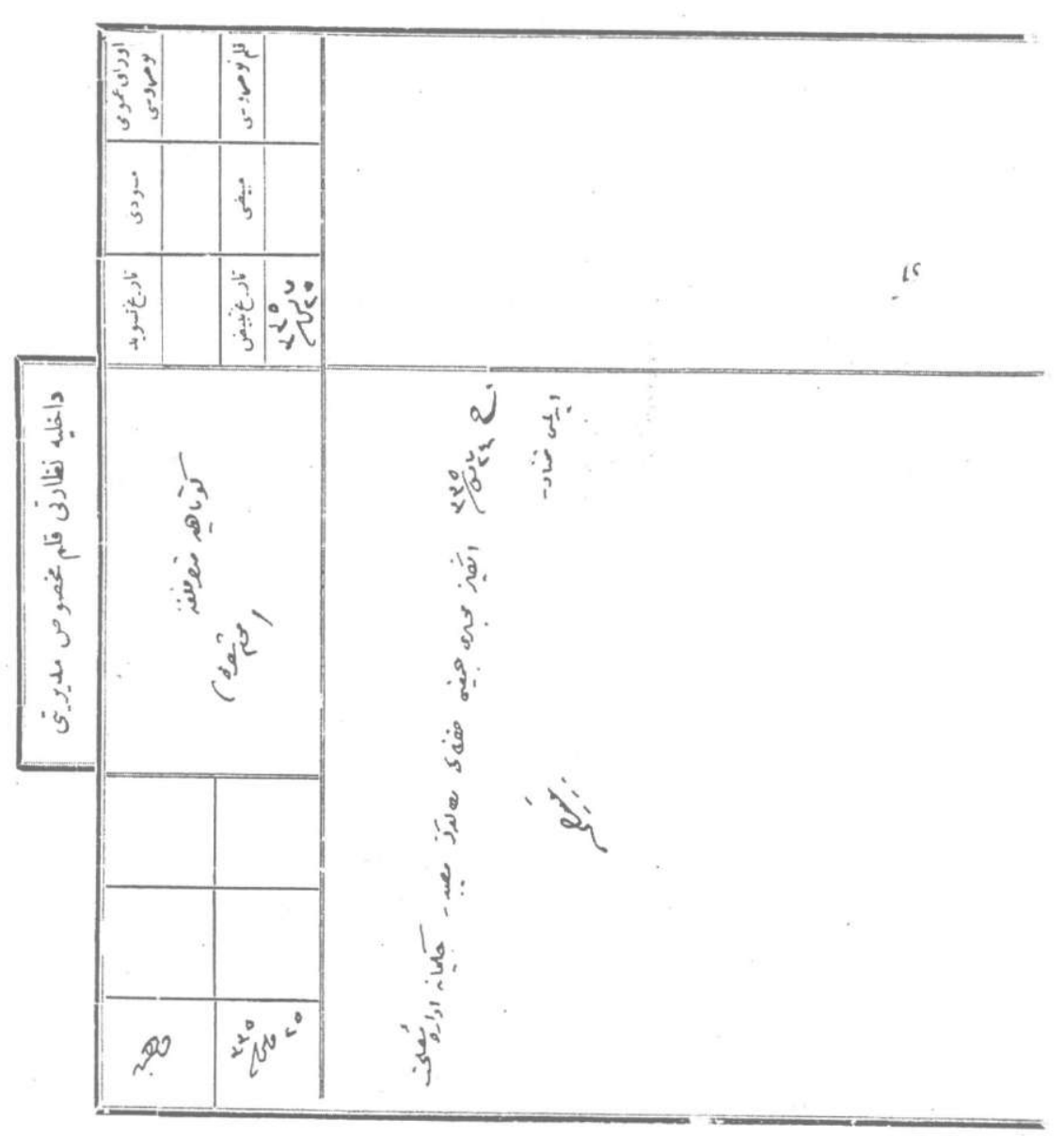

